
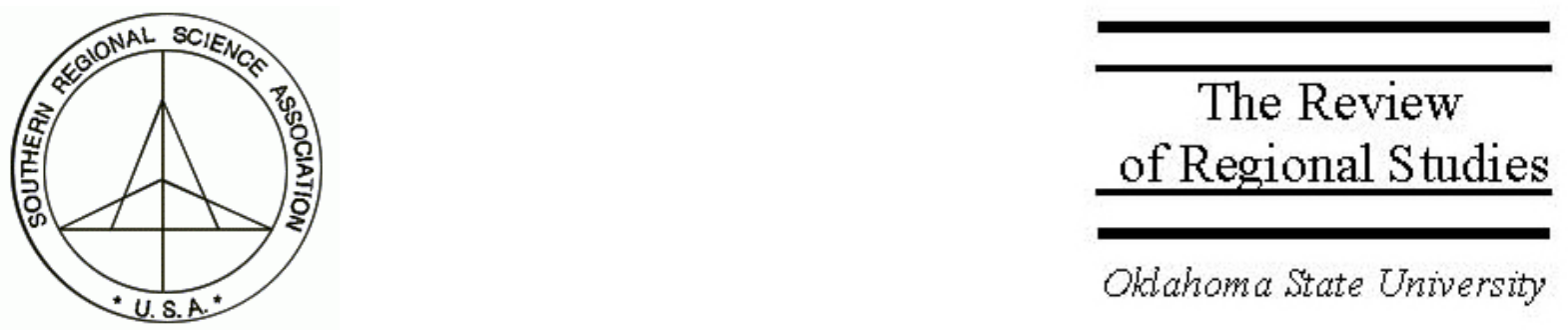

\title{
Convergence Across Spanish Regions: New Evidence on the Effects of Public Investment ${ }^{*}$
}

\author{
Jose Manuel Gonzalez-Paramo \\ University Complutense of Madrid and Bank of Spain \\ C/ Alcala, 50,28014, Madrid, Spain,e-mail: jmgparamo@bde.es. \\ Diego Martinez \\ University of Jaen and Fundacion Centro de Estudios Andaluces \\ C/Bailen, 50, 41001 Seville, Spain,e-mail:dmartinez@fundacion-centra.org.
}

\begin{abstract}
We examine the empirical relationship between public investment and per capita income growth in the Spanish regions over 1965-1997. Using a neoclassical growth model with public and human capital, a convergence equation is derived and estimated using panel data techniques. Besides providing evidence of conditional convergence, the results show a non-positive effect of productive-public investment on the rate of regional economic growth. The impact of public investment in education and health is not clear. Robustness checks addressing potential endogeneity and specification problems reaffirm our results. It is concluded that there are no simple recipes for effective regional investment policies.
\end{abstract}

\footnotetext{
${ }^{*}$ We are grateful to Javier Rodero and participants at the International Symposium on Economic Modelling, at the VII Encuentro de Economia Publica, at the $49^{\text {th }}$ Meeting of the North American Regional Science Association, at the XXVIII reunion de Estudios Regionales, at the XXVII Simposio de Analisis Economico, two anonymous referees, and the editor Dan Rickman for their suggestions. Thanks are also due to A.J. Sanchez and E. Ruiz for their research assistance. All remaining errors are ours.
} 


\section{INTRODUCTION}

The academic interest in the effects of regional policies on economic performance has been fostered in recent years by the debate on the impact of economic integration in the EU upon regional convergence. Some authors argue that such integration will negatively affect peripheral regions due to agglomeration economies and other factors. A different strand of research posits, on the contrary, that regional convergence may obtain as a result of public policies. Among other public interventions, public investment appears as the main instrument for reducing differences in regional per capita income levels.

In the literature the relationship between public investment and regional growth has been studied from different perspectives. For instance, Biehl (1986) elaborates a regional index of endowments in different infrastructures and relates it to per capita GDP, showing a high positive correlation between both variables, and Vickerman (1991) emphasizes the importance of transport infrastructure in the production processes that enlarge the benefits of the common market for regions geographically outlying.

Economic growth models have also treated this question. Although the incorporation of public capital was already considered in a neoclassical model by Arrow and Kurz (1970), it was not until the seminal articles of Aschauer (1989), Barro (1990), and Munnell (1990) that the topic began to be studied in a systematic fashion. Barro builds an endogenous growth model where per capita income growth rate is sustained by existence of public capital. The extensions building on this approach have been abundant, with novel contributions on congestion (Glomm and Ravikumar 1994; Fisher and Turnovsky 1998), transitional dynamics (Futagami, Morita, and Shibata 1993), implications for social welfare (Gonzalez-Paramo 1995; Dasgupta 1999), inclusion of other public spending variables (Bajo-Rubio 2000), and finance under different tax systems (Jones, Manuelli, and Rossi 1993; Kneller, Bleaney, and Gemmell 1999).

The neoclassical literature offers contradictory evidence on the effects of public investment on the growth rate. In an early study, Barro (1991) pointed out the existence of a weak negative relationship between public investment and growth rates in a cross-section analysis for almost 90 countries over 1965 to 1985. In the same vein, Evans and Karras (1994) show through a panel data analysis that public capital does not affect positively to the growth rate of a group of OECD countries over 1963 to 1983. However, Knight, Loayza, and Villanueva (1993) offer evidence in favor of a direct relationship between public investment and growth. De la Fuente (1997) also finds a positive effect of public investment on growth in OECD countries, although subject to decreasing returns.

From a regional perspective, the availability of published studies that explicitly relate public investment to growth through estimations of convergence equations is rather limited. In a classic paper, Hulten and Schwab (1993) estimate a convergence equation for U.S. manufacturing and do not detect a direct effect of public capital on productivity for the 1970 to 1986 period. Thomas (1996) evaluates the impact of the stock of infrastructure on growth rates for 70 European regions from 1970 to 1991 and concludes that when considered by category, regional endowments of infrastructure do not exert any significant effect on per capita income growth, while an index of overall endowments is positively related to growth. Dalenberg and Partridge 
$(1995,1997)$ examine the effects of highway and other public spending on employment in aggregate and for specific sectors among U.S. metropolitan areas over a 15-year period. The research accounts for the entire set of government fiscal policies by including measures of all taxes and spending categories (relative to one omitted category). The study actually reports a significant negative relationship between development and highway spending. A negative relationship between public infrastructure investment and productivity growth is also found by Holtz-Eakin (1994) for a panel of U.S. states.

If we restrict our interest to the Spanish case, Mas et al. (1994) find evidence in favor of a positive effect of public capital on regional convergence over the period 1955 to 1991, although in estimations for shorter periods of time this result ceases to hold. Dolado, Gonzalez-Paramo, and Roldan (1994) do not find any explanatory capacity for highway and road infrastructure in convergence equations estimated for the Spanish provinces from 1955 to 1989. De la Fuente and Vives (1995) recognise the importance of public capital endowments in the determination of per capita regional income, although they indicate that the impact of regional policies in Spain during the 1980s has been small. Bajo, Diaz, and Montavez (1999) also detect a positive and significant effect of public investment on regional GDP. However, a recent work of Gorostiaga (1999) estimates a positive but statistically insignificant effect of public investment on the convergence rate.

While some of the previous studies have considered human capital when analysing the role of public investment on growth, none of them has taken into account the government budget constraint. In the present paper we examine the empirical relationship between public investment and per capita income growth in the Spanish regions over the period 1965 to 1997. A convergence equation is derived from a neoclassical model with public capital and human capital. We estimate the convergence equation through panel data techniques. Our work explicitly considers public investment in core infrastructure and human capital and treats separately the effects of tax revenues and productive public spending.

The theoretical framework is presented in Section 2. Section 3 describes the estimation procedure used and discusses the results obtained under different specifications for the convergence equation. Next we consider the econometric implications of the potential endogeneity of some regressors. Section 5 provides alternative specifications of the convergence equation, with the inclusion of multiplicative dummies and nonlinear relationships between public investment and per capita income growth. Section 6 discusses our results in relation to other theoretical contributions in the literature. Finally, Section 7 concludes the paper.

\section{THEORETICAL FRAMEWORK}

Our theoretical model is based on the well-known Solow (1956) growth model and follows the by now standard framework provided by Mankiw, Romer, and Weil (1992). In this section we provide the most general version of the model, including simultaneously private, public, and human capital as production factors. Alternative specifications in the empirical estimation can be easily derived from the model presented here. 
We assume a Cobb-Douglas production function with decreasing returns in factors for region $i$ at time $t$ :

$$
Y_{i t}=\left(\psi_{i t} L_{i t}\right)^{1-\alpha-\beta-\gamma}\left(K_{i t}\right)^{\alpha}\left(G_{i t}\right)^{\beta}\left(H_{i t}\right)^{\gamma},
$$

where $\psi_{i t}=\psi_{i 0} e^{x t}$ and $L_{i t}=L_{o}^{i} e^{n i t}, Y$ is regional output, $\psi_{i 0}$ is a parameter that reflects unobserved characteristics of region $i$ (resource endowments, climate, institutions, etc.), $L$ is labor, $K$ is private capital, $G$ is productive public capital, and $H$ is human capital, with $\alpha+\beta+\gamma<1$. Technology and labor grow exogenously at constant rates $x$ and $n$, respectively. If we assume constant returns to scale in all inputs, we can rewrite expression (1A) in terms of effective labor:

$$
\hat{y}_{i t}=\left(\hat{k}_{i t}\right)^{\alpha}\left(\hat{g}_{i t}\right)^{\beta}\left(\hat{h}_{i t}\right)^{\gamma} \text {, }
$$

where $\hat{w}_{i}=W_{i} / \psi_{i} L_{i}$, for $W=Y, K, G, H$. Next we define the capital accumulation equations:

$$
\begin{aligned}
& \dot{\hat{k}}_{i t}=\left(1-\tau_{i t}\right) s_{p i} \hat{y}_{i t}-\left(\delta+n_{i}+x\right) \hat{k}_{i t} \\
& \dot{\hat{g}}_{i t}=s_{g i} \hat{y}_{i t}-\left(\delta+n_{i}+x\right) \hat{g}_{i t} \\
& \dot{\hat{h}}_{i t}=\left(1-\tau_{i t}\right) s_{h i} \hat{y}_{i t}-\left(\delta+n_{i}+x\right) \hat{h}_{i t},
\end{aligned}
$$

where a dot over a variable denotes its time derivative, $\tau$ is the share of tax revenues over total output, $s_{p i}$ is the (constant) share of gross private investment in physical capital over output net taxes, $s_{h i}$ is the equivalent concept for human capital, $\delta$ is the depreciation rate (assumed constant and common to all types of capital), and $s_{g i}$ is the share of gross public investment over output.

When equations in (2) are expressed in terms of growth rates and solved for state variables, we easily obtain the steady-state values of private capital $\left(\hat{k}_{i}^{*}\right)$, productive public capital $\left(\hat{g}_{i}^{*}\right)$, human capital $\left(\hat{h}_{i}^{*}\right)$, and output $\left(\hat{y}_{i}^{*}\right)$. Taking logs in (1B) and differentiating with respect to time, we obtain:

$$
\frac{d \ln y_{i}}{d t}=\frac{d \ln \psi_{i}}{d t}+\alpha \frac{d \ln \hat{k}_{i}}{d t}+\beta \frac{d \ln \hat{g}_{i}}{d t}+\gamma \frac{d \ln \hat{h}_{i}}{d t}
$$

Upon rewriting equation (3) in terms of the growth rate of income per effective labor, if we use the growth rates of production factors from system (2), we get the following expression:

$$
\begin{aligned}
\frac{d \ln \hat{y}_{i}}{d t}= & \alpha\left[(1-\tau) s_{p i} e^{(\alpha-1) \ln k} e^{\beta \ln g} e^{\gamma \ln h}\right]+\beta\left[s_{g i} e^{\alpha \ln k} e^{(\beta-1) \ln g} e^{\gamma \ln h}\right]+ \\
& \gamma\left[(1-\tau) s_{h i} e^{\alpha \ln k} e^{\beta \ln g} e^{(\gamma-1) \ln h}\right]-(\alpha+\beta+\gamma)\left(\delta+n_{i}+x\right) .
\end{aligned}
$$


A first-order Taylor approximation of this expression around steady-state values yields:

$$
\frac{d \ln \hat{y}_{i t}}{d t} \approx-\alpha \lambda\left(\ln \hat{k}_{i t}-\ln \hat{k}_{i}^{*}\right)-\beta \lambda\left(\ln \hat{g}_{i t}-\ln \hat{g}_{i}^{*}\right)-\gamma \lambda\left(\ln \hat{h}_{i t}-\ln \hat{h}_{i}^{*}\right)=-\lambda\left(\ln \hat{y}_{i t}-\ln \hat{y}_{i}^{*}\right),
$$

where $\lambda=(1-\alpha-\beta-\gamma)\left(\delta+n_{i}+x\right)$ can be interpreted as the speed of convergence to steady state, i.e., the annual rate of convergence at which the economy moves to its own steady state. Solving the differential equation (5) and expressing all variables in per capita terms, we obtain the convergence equation:

$$
\begin{aligned}
& \ln y_{i t}-\ln y_{i t-T}=\rho \ln \psi_{i 0}+x\left(t-e^{-\lambda \mathrm{T}}(t-T)\right)-\rho \ln y_{i t-T}+\rho \frac{\alpha}{1-\alpha-\beta-\gamma} \ln s_{p i t}+ \\
& \rho \frac{\beta}{1-\alpha-\beta-\gamma} \ln s_{g i t}+\rho \frac{\gamma}{1-\alpha-\beta-\gamma} \ln s_{h i t}-\rho \frac{\alpha+\beta+\gamma}{1-\alpha-\beta-\gamma} \ln \left(\delta+n_{i t}+x\right) \\
& \rho \frac{\alpha+\gamma}{1-\alpha-\beta-\gamma} \ln \left(1-\tau_{i t}\right)
\end{aligned}
$$

where $\ln y_{i t-T}$ is the log of per capita income at the beginning of the period of length $T$ and $\rho=1-e^{-\lambda t}$. The parameter $\psi_{i 0}$ captures unobservable differences across regions.

In the next section we econometrically estimate equation (6). Note that the model includes public spending and taxes collected by government. This specification enables us to evaluate the role of the public sector taking into account both sides of the public budget.

\section{BASIC ESTIMATION RESULTS}

Most empirical contributions to the growth literature proceed by estimating the speed of convergence and the effects of conditioning variables on growth rates by means of cross-section analysis. This methodology uses the Ordinary Least Squares (OLS) estimation procedure, which can in principle control for the existence of different steady states across economies. However, as pointed out by Islam (1995), OLS applied to a cross section does not allow us to consider unobservable regional characteristics, thus yielding potentially biased estimates. A panel data approach overcomes this problem and allows us to capture the time dimension in an appropriate fashion. ${ }^{1}$

To examine regional convergence in Spain, data for the 17 Spanish regions over the period 1965-1997 are used. The rate of regional unemployment $\left(u_{i t}\right)$ has been included to control for the effects of the business cycle. The estimated model is that in equation (6) with the inclusion of an error term that is assumed normally distributed with zero mean and constant variance. Three different measures of investment in human capital $\left(s_{h}\right)$ were used as proxies: public investment in education $\left(s_{e}\right)$, public investment in health $\left(s_{d}\right)$, and the sum of both investment categories

\footnotetext{
${ }^{1}$ However, panel data studies can sometimes be deceiving because of specification problems (see De la Fuente 2000).
} 
$\left(s_{s}\right) .^{2}$ Details on the definition of variables and statistical sources can be found in the Data Appendix.

The term reflecting technical progress, $x\left(t-e^{-\lambda \mathrm{T}}(t-T)\right)$, depends on exogenous, constant variables; so its effect is captured in the regional constant $\ln \psi_{i 0}$. In order to isolate technical progress, we tried previously a time trend; but this specification caused multicollinearity problems, mainly due to the presence of $\left(1-\tau_{i t}\right)$ and $y_{i t-1 .}{ }^{3}$

Our basic estimation results are displayed in Table 1. Given that the Hausman tests (Hausman 1978) provide evidence on the existence of correlations between individual effects and the regressors, the results presented are obtained using a fixed effects (within groups) estimator. All the estimation exercises have been carried out weighting the observations in the cross-section to avoid heteroskedasticity caused by the different size of the units. We also used a White covariance matrix.

As is customary in empirical work on economic convergence, the results presented in Table 1 are obtained imposing the restriction that the sum of the coefficients on the demographic variables, the private investment rate, and the public investment rate in infrastructure and human capital is zero. This hypothesis cannot be rejected, as indicated by the Wald tests. An F test is also included to evaluate the joint significance of the regional fixed effects. In specifications (3)(6) the null hypothesis (i.e., a common constant term for all regions) is rejected at the 1 percent; however, the null is not rejected in specifications (1)-(2). Nonetheless, economic intuition suggests that regional characteristics exist, and they are not controlled for in our analysis explicitly. Thus, in order to facilitate comparisons with later specifications, we have included the estimates that allow a different constant for each region.

From Table 1 we can draw some preliminary results about the interrelations between regional convergence and public sector performance in Spain. First, we find conditional $\beta$-convergence among regions toward their own steady states. The speed of convergence ranges from two to ten percent per year, depending on the specification. The results reported in columns (1) and (2) are in line with those of Barro and Sala-i-Martin (1999), who estimate a speed of convergence close to three percent. Specifications (3)-(5) yield convergence rates of four to five percent, consistent with those obtained by Dolado, Gonzalez-Paramo, and Roldan (1994). The last specification column 6 - produces a rate of convergence of 11 percent per year, a value close to that obtained by Islam (1995) for OECD countries when human capital is included as a stock variable. Nevertheless, there are indications that this last estimation may be affected by multicollinearity, so the later result should be interpreted with some caution.

Regarding the role of private investment, this variable presents the positive signs predicted by the theoretical model; in every case its statistical significance is accepted. The human capital effect, on the other hand, is not clear because it only appears with a positive significant sign

\footnotetext{
${ }^{2}$ Although not very usual, the use of social public capital as a proxy for human capital is not a novelty in the literature (see, for example, Currais and Rivera 1999a, 1999b).

${ }^{3}$ Easterly and Rebelo (1993) emphasize the close relationship of the tax variable with other regressors in the growth equations, being difficult to isolate the effects of the taxation in presence of multicollinearity.
} 


\section{TABLE 1}

Estimation of Convergence Equation. Spanish Regions (1965 - 1997)

(Dependent Variable: Per Capita Income Growth Rate)

\begin{tabular}{|c|c|c|c|c|c|c|}
\hline & (1) & (2) & (3) & (4) & (5) & (6) \\
\hline $\log \left(y_{i, t-T}\right)$ & $\begin{array}{l}-0.046 \\
(-4.73)\end{array}$ & $\begin{array}{l}-0.054 \\
(-4.77)\end{array}$ & $\begin{array}{l}-0.090 \\
(-8.15)\end{array}$ & $\begin{array}{l}-0.088 \\
(-8.19)\end{array}$ & $\begin{array}{l}-0.102 \\
(-9.64)\end{array}$ & $\begin{array}{l}-0.210 \\
(-10.73)\end{array}$ \\
\hline $\log \left(s_{p i t}\right)-\log \left(n_{i t}+x+\delta\right)$ & $\begin{array}{r}0.026 \\
(3.79)\end{array}$ & $\begin{array}{r}0.026 \\
(3.77)\end{array}$ & $\begin{array}{r}0.030 \\
(4.75)\end{array}$ & $\begin{array}{r}0.031 \\
(4.96)\end{array}$ & $\begin{array}{r}0.026 \\
(4.16)\end{array}$ & $\begin{array}{r}0.034 \\
(5.94)\end{array}$ \\
\hline $\log \left(s_{g i t}\right)-\log \left(n_{i t}+x+\delta\right)$ & & $\begin{array}{r}0.012 \\
(3.11)\end{array}$ & $\begin{array}{l}-0.004 \\
(-0.91)\end{array}$ & $\begin{array}{l}-0.002 \\
(-0.59)\end{array}$ & $\begin{array}{l}-0.008 \\
(-1.84)\end{array}$ & $\begin{array}{l}-0.002 \\
(-0.60)\end{array}$ \\
\hline $\log \left(s_{s i t}\right)-\log \left(n_{i t}+x+\delta\right)$ & & $\begin{array}{l}-0.0007 \\
(-0.19)\end{array}$ & $\begin{array}{r}0.001 \\
(0.31)\end{array}$ & & & \\
\hline $\log \left(s_{e i t}\right)-\log \left(n_{i t}+x+\delta\right)$ & & & & $\begin{array}{r}-0.003 \\
(-1.30)\end{array}$ & & \\
\hline $\log \left(s_{d i t}\right)-\log \left(n_{i t}+x+\delta\right)$ & & & & & $\begin{array}{r}0.010 \\
(4.21)\end{array}$ & \\
\hline $\log \left(h_{i t}\right)$ & & & & & & $\begin{array}{r}0.064 \\
(6.72)\end{array}$ \\
\hline $\log \left(u_{i t}\right)$ & $\begin{array}{l}0.00003 \\
(0.02)\end{array}$ & $\begin{array}{l}-0.0008 \\
(-0.43)\end{array}$ & $\begin{array}{l}-0.008 \\
(-3.77)\end{array}$ & $\begin{array}{l}-0.008 \\
(-3.88)\end{array}$ & $\begin{array}{r}-0.007 \\
(-3.50)\end{array}$ & $\begin{array}{l}-0.014 \\
(-6.62)\end{array}$ \\
\hline $\log \left(1-\tau_{i t}\right)$ & & & $\begin{array}{r}-0.319 \\
(-6.68)\end{array}$ & $\begin{array}{l}-0.317 \\
(-6.67)\end{array}$ & $\begin{array}{l}-0.337 \\
(-7.30)\end{array}$ & $\begin{array}{l}-0.076 \\
(-1.24)\end{array}$ \\
\hline$\lambda$ & 0.023 & 0.027 & 0.047 & 0.046 & 0.053 & 0.117 \\
\hline RSS & 0.118 & 0.113 & 0.099 & 0.098 & 0.095 & 0.079 \\
\hline Durbin-Watson & 1.56 & 1.65 & 1.63 & 1.63 & 1.66 & 1.44 \\
\hline Hausman & $\begin{array}{l}25.19 \\
{[0.000]}\end{array}$ & $\begin{array}{c}9.49 \\
{[0.09]}\end{array}$ & $\begin{array}{l}45.77 \\
{[0.000]}\end{array}$ & $\begin{array}{l}48.61 \\
{[0.00]}\end{array}$ & $\begin{array}{l}123.03 \\
{[0.000]}\end{array}$ & $\begin{array}{c}262.02 \\
{[0.00]}\end{array}$ \\
\hline Wald $\left(\chi^{2}\right)$ & $\begin{array}{l}0.51 \\
{[0.47]}\end{array}$ & $\begin{array}{l}0.0003 \\
{[0.98]}\end{array}$ & $\begin{array}{c}0.57 \\
{[0.45]}\end{array}$ & $\begin{array}{r}0.052 \\
{[0.81]}\end{array}$ & $\begin{array}{c}2.11 \\
{[0.14]}\end{array}$ & $\begin{array}{c}1.27 \\
{[0.26]}\end{array}$ \\
\hline $\mathrm{F}$ & $\begin{array}{c}1.08 \\
{[16,249]}\end{array}$ & $\begin{array}{c}1.56 \\
{[16,247]}\end{array}$ & $\begin{array}{c}4.076 \\
{[16,246]}\end{array}$ & $\begin{array}{c}3.80 \\
{[16,246]}\end{array}$ & $\begin{array}{c}4.61 \\
{[16,246]}\end{array}$ & $\begin{array}{c}7.56 \\
{[16,246]}\end{array}$ \\
\hline
\end{tabular}

when is it defined as a stock variable (column 6) or when it is approximated through public investment in health (column 5). ${ }^{4}$ With regard to education, it is worth noting that public investment in education is not statistically significant in explaining regional per capita income growth. This startling conclusion is not new in the empirical literature (Gorostiaga 1999; Wolf 2000).

Our results also suggest that productive public investment, $s_{g i t}$, has not contributed to the growth rate of Spanish regions. In fact, we find a negative sign in four out five specifications including this variable. This finding calls for further analysis, since it puts into question the commonly shared belief that public capital endowments play an important role in regional development. We take up this issue in the following sections of the paper.

\footnotetext{
${ }^{4}$ This last result is, partially, in the line of Rivera and Currais (2000) for the OECD countries. These authors determine that current health spending and capital health spending exert a positive influence on growth rate, although the estimated coefficient for the second of these variables is not significant.
} 
Finally, the share of income available for private capital accumulation after discounting for taxes, $\left(1-\tau_{i t}\right)$, appears with a negative sign, against theoretical expectation. This finding could result from the sizable expansion of the Spanish public sector over the period of analysis. ${ }^{5}$ Regarding unemployment rate, $u_{i t}$, its negative sign in all specifications is consistent with economic theory.

\section{AN ALTERNATIVE ANALYSIS: ENDOGENEITY OF THE REGRESSORS}

Endogeneity of some regressors in the equation might result in inconsistent estimations. This could explain, at least partially, the lack of significance and the sign of the effect of public investment on infrastructure. The literature on economic growth has shown that the rate of private investment depends on income growth rate (see King and Levine 1994; Dolado, Gonzales-Paramo, and Roldan 1994; and Gorostiaga 1999). On the other hand, the possible simultaneity of infrastructure with output (see, for example, Sturm 1998), could generate an inverse causation that biases the estimate.

In order to examine the impact of endogeneity, here we estimate the convergence equation using an instrumental variables (IV) estimator. We also employ the Generalised Method of Moments (GMM) to select the optimal instruments matrix. In the following we refer to a specification of column 3 of Table 1 . This specification is sufficiently general to illustrate the implications of a likely endogeneity. ${ }^{6}$ Since the estimator is a within-groups estimator, the use of lagged regressors as instruments is not the best option. Instead, we employ the transformation of variables in orthogonal deviations, as suggested by Arellano (1988).

As is well known, when there are more instruments available than parameters to estimate, the model is overidentified. A Sargan test of overidentifying restrictions can be interpreted as a test on the validity of the group of instruments and the appropriate specification. On the other hand, keeping in mind that the assumption of absence of serial correlation in the disturbances is essential for the consistency of estimators, this hypothesis should be tested. Here, we adopt the strategy suggested by Arellano and Bond (1991): if the errors are not correlated, the series of differences of residuals should present a significant first-order correlation, while indications of second-order serial correlation ought not to be present. In the results that we offer, none of the statistics used to check for these implies evidence of serial correlation in the errors.

Table 2 summarizes the estimates of the convergence equation for five different sets of instruments. These new results are quite similar to those presented previously. Indeed, they support the evidence of conditional $\beta$-convergence with speeds towards the steady state of around five percent. Again, negative coefficients are obtained for public investment and positive ones (but not significant) for human capital. The coefficients estimated for the unemployment rates and income share available for capital accumulation also remain unchanged. The Sargan

\footnotetext{
${ }^{5}$ The theoretical framework used in this paper does not present enough scope to deal with the (in)efficiency of taxation. For a detailed analysis of the taxation effects on growth, see Mendoza, Milesi-Ferreti, and Asea (1997) and Domenech and Garcia (2001). As we have already said, Easterly and Rebelo (1993) also show the difficulties of isolating the influence of the tax system on economic growth.

${ }^{6}$ Estimates of alternative specifications are available on request. They corroborate the results obtained for the equation that serves as our reference.
} 


\section{TABLE 2}

GMM Estimation of Convergence Equation. Spanish Regions (1965 - 1997) (Dependent Variable: Per Capita Income Growth Rate)

\begin{tabular}{|c|c|c|c|c|c|}
\hline & (1) & (2) & (3) & (4) & (5) \\
\hline $\log \left(y_{i, t-T}\right)$ & $\begin{array}{r}-0.104 \\
(-12.51)\end{array}$ & $\begin{array}{c}-0.092 \\
(-9.97)\end{array}$ & $\begin{array}{c}-0.092 \\
(-9.50)\end{array}$ & $\begin{array}{c}-0.093 \\
(-10.04)\end{array}$ & $\begin{array}{c}-0.094 \\
(-9.97)\end{array}$ \\
\hline $\log \left(s_{p i t}\right)-\log \left(n_{i t}+x+\delta\right)$ & $\begin{array}{r}0.037 \\
(4.86)\end{array}$ & $\begin{array}{r}0.029 \\
(4.40)\end{array}$ & $\begin{array}{c}0.032 \\
(5.31)\end{array}$ & $\begin{array}{c}0.029 \\
(4.45)\end{array}$ & $\begin{array}{c}0.032 \\
(4.68)\end{array}$ \\
\hline $\log \left(s_{g i t}\right)-\log \left(n_{i t}+x+\delta\right)$ & $\begin{array}{c}-0.005 \\
(-1.51)\end{array}$ & $\begin{array}{l}-0.002 \\
(-0.49)\end{array}$ & $\begin{array}{l}-0.0006 \\
(-0.15)\end{array}$ & $\begin{array}{l}-0.002 \\
(-0.67)\end{array}$ & $\begin{array}{l}-0.002 \\
(-0.84)\end{array}$ \\
\hline $\log \left(s_{s i t}\right)-\log \left(n_{i t}+x+\delta\right)$ & $\begin{array}{l}0.0008 \\
(0.32)\end{array}$ & $\begin{array}{c}0.001 \\
(0.66)\end{array}$ & $\begin{array}{l}0.0008 \\
(0.35)\end{array}$ & $\begin{array}{r}0.001 \\
(0.78)\end{array}$ & $\begin{array}{c}0.003 \\
(1.37)\end{array}$ \\
\hline $\log \left(u_{i t}\right)$ & $\begin{array}{l}-0.007 \\
(-3.25)\end{array}$ & $\begin{array}{l}-0.005 \\
(-3.41)\end{array}$ & $\begin{array}{l}-0.005 \\
(-3.33)\end{array}$ & $\begin{array}{l}-0.005 \\
(-3.34)\end{array}$ & $\begin{array}{l}-0.005 \\
(-3.37)\end{array}$ \\
\hline $\log \left(1-\tau_{i t}\right)$ & $\begin{array}{r}-0.357 \\
(-9.39)\end{array}$ & $\begin{array}{l}-0.276 \\
(-6.52)\end{array}$ & $\begin{array}{c}-0.271 \\
(-6.16)\end{array}$ & $\begin{array}{c}-0.282 \\
(-6.19)\end{array}$ & $\begin{array}{r}-0.279 \\
(-7.50)\end{array}$ \\
\hline$\lambda$ & 0.054 & 0.048 & 0.048 & 0.048 & 0.049 \\
\hline RSS & 0.102 & 0.100 & 0.100 & 0.100 & 0.083 \\
\hline$m_{1}$ & 3.542 & 3.584 & 3.607 & 3.565 & 3.644 \\
\hline$m_{2}$ & -2.882 & -2.826 & -2.786 & -2.797 & -2.754 \\
\hline Sargan & $\begin{array}{r}188.88 \\
{[84]}\end{array}$ & $\begin{array}{r}150.94 \\
{[28]}\end{array}$ & $\begin{array}{r}190.70 \\
{[56]}\end{array}$ & $\begin{array}{r}177.25 \\
{[28]}\end{array}$ & $\begin{array}{r}199.97 \\
{[84]} \\
\end{array}$ \\
\hline
\end{tabular}

Notes: Instruments set in each specification: (1) $\log \left(\mathrm{s}_{\mathrm{pit}}\right)-\log \left(\mathrm{n}_{\mathrm{it}}+\mathrm{x}+\delta\right)$ and $\log \left(1-\tau_{\mathrm{it}}\right)$ with one $\operatorname{lag}, \log \left(\mathrm{s}_{\mathrm{git}}\right)$ and $\log \left(\mathrm{s}_{\mathrm{sit}}\right)$ with one and two lags and remaining variables as exogenous. (2) $\log \left(\mathrm{s}_{\mathrm{git}}\right)-\log \left(\mathrm{n}_{\mathrm{it}}+\mathrm{x}+\delta\right)$ with one and two lags and remaining variables as exogenous. (3) $\log \left(\mathrm{s}_{\mathrm{pit}}\right)-\log \left(\mathrm{n}_{\mathrm{it}}+\mathrm{x}+\delta\right)$ y $\log \left(\mathrm{s}_{\mathrm{git}}\right)-\log \left(\mathrm{n}_{\mathrm{it}}+\mathrm{x}+\delta\right)$ with one and two lags and the remaining variables as exogenous. (4) $\log \left(\mathrm{s}_{\mathrm{git}}\right)$ with one and two lags and the remaining variables as exogenous. (5) $\log \left(\mathrm{s}_{\mathrm{pit}}\right)-\log \left(\mathrm{n}_{\mathrm{it}}+\mathrm{x}+\delta\right), \log \left(\mathrm{s}_{\mathrm{git}}\right), \log \left(\mathrm{s}_{\text {sit }}\right)$ with one and two lags and the remaining variables as exogenous.

t-ratios are shown in parentheses. Degrees of freedom in brackets. Robust standard deviations for the presence of heteroskedasticity between units. Number of observations: 255 (Orthogonal deviation transformation reserves one extra observation; see data appendix). Source: IVIE and Foundation BBVA.

tests of overidentifying restrictions reject the different groups of instruments. ${ }^{7}$ This implicit rejection of endogeneity hypothesis for public and private investment is not new in the literature (De Long and Summers 1991; Clarida 1993; Hulten and Schwab 1993).

\section{OTHER RESULTS OBTAINED UNDER DIFFERENT SPECIFICATIONS}

In this section we further check the robustness of the previous results. We will study the results derived from different variants of the previous convergence equation. First we introduce

\footnotetext{
${ }^{7}$ The results are robust for different definitions of the matrix of instruments. Arellano and Bond (1991) demonstrate the trend to over-reject the null hypothesis of the Sargan test in the presence of heteroskedasticity. Since the option of estimating via two-step GMM was excluded before, we could have identified one of the factors that cooperate in the widespread rejection of the selected matrix of instruments. Instead, a remarkable sensitivity of the results is not appreciated regarding the choice of the matrix of instruments.
} 
regional multiplicative dummies in the coefficients for public investment in order to isolate differential effects on regional growth. Second we include nonlinear relationships between productive and social public investment and the regional growth rate.

\subsection{Regional Multiplicative Dummies}

A first option is the inclusion of multiplicative dummy variables in the coefficients of public investment in addition to the estimated dummies as unobservable fixed effects. This allows us to observe how the different components of public investment affect each region. The results are displayed in Table 3.

Two main conclusions can be drawn from Table 3. First, the variables whose specification is not modified with the inclusion of multiplicative dummies maintain their values and significance levels. Further, the negative aggregate effect of productive public investment becomes significant in one specification (column 6). Second, few of the regional coefficients are significant. A positive impact of public investment on growth is found for La Rioja, while the opposite is true for Asturias (columns 1 to 3). In turn, health public investment has exerted positive effects in Aragon, Castilla-Leon, Madrid, and Murcia (column 6). ${ }^{8}$

\subsection{Nonlinear Relationships Between Public Investment and Regional Growth}

Let us now consider a specification of the convergence equation that takes into account the possibility of nonlinear relationships between regional growth rate and public investment. De la Fuente (1997) uses a nonlinear specification for the convergence equation in order to evaluate the links between government investment and growth in a sample of OECD countries. A recent paper by Aschauer (2000) detects a positive, nonlinear relationship between both variables for 48 U.S. states. In order to check for the presence of nonlinearities, we modify our equation (6) by adding quadratic terms for public investment in productive capital and human capital:

$$
\begin{aligned}
& \ln y_{i t}-\ln y_{i t-T}=\beta_{0} \ln \psi_{i 0}+x\left(t-e^{-\lambda t}(t-T)\right)-\beta_{1} \ln y_{i t-T}+\beta_{2} \ln s_{p i t}+\beta_{3} \ln s_{g i t}+ \\
& \beta_{4}\left(\ln s_{g i t}\right)^{2}+\beta_{5} \ln s_{h i t}+\beta_{6}\left(\ln s_{h i t}\right)^{2}+\beta_{7} \ln \left(\delta+n_{i t}+x\right)+\beta_{8}\left(1-\tau_{i t}\right) .
\end{aligned}
$$

Table 4 shows the results of the within-groups estimator. ${ }^{9}$ Once again, the coefficients of variables that have not been modified in the equation remain close to the values and statistical significance obtained previously. Productive public investment continues to be statistically nonsignificant. Social public investment gains statistical significance and even changes from a positive sign to a negative one when it enters as a quadratic term in the equation. This result cou/ld be linked to decreasing returns in public capital (see De la Fuente 1997). Both public investment in education and public investment in health exert now a negative effect on regional economic growth, even for nonlinear terms.

\footnotetext{
${ }^{8}$ A possible extension of this strategy could be the constitution of regional clubs. However, we would have to deal with a smaller number of observations.

${ }^{9}$ As in the previous case, we do not show the values of other statistics such as Hausman or F. Their values support the chosen specification.
} 
TABLE 3

Estimation of Convergence Equation with Multiplicative Dummies, Spanish Regions (1965 - 1997) (Dependent Variable: Per Capita Income Growth Rate)

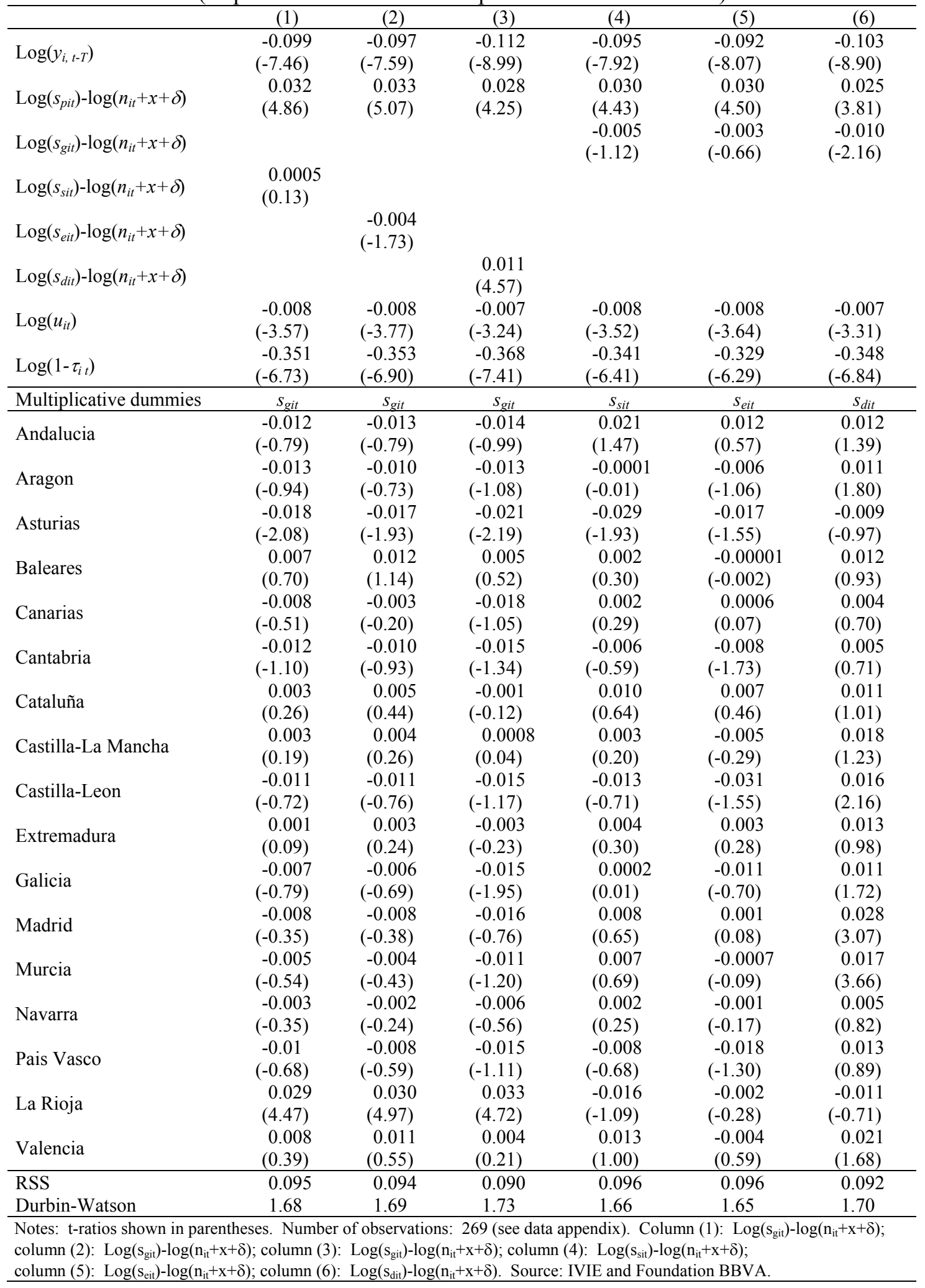




\section{TABLE 4}

Estimation of Convergence Equation With Nonlinear Relationships, Spanish Regions (1965 - 1997) (Dependent Variable: Per Capita Income Growth Rate)

\begin{tabular}{|c|c|c|c|c|c|}
\hline & $(1)$ & (2) & (3) & (4) & $(5)$ \\
\hline \multirow{2}{*}{$\log \left(y_{i, t-T}\right)$} & -0.095 & -0.096 & -0.093 & -0.087 & -0.112 \\
\hline & $(-7.36)$ & $(-7.38)$ & $(-7.16)$ & $(-7.15)$ & $(-9.01)$ \\
\hline \multirow{2}{*}{$\log \left(s_{p i t}\right)$} & 0.034 & 0.033 & 0.031 & 0.030 & 0.032 \\
\hline & $(4.20)$ & $(4.18)$ & $(3.77)$ & $(3.70)$ & $(4.06)$ \\
\hline \multirow{2}{*}{$\log \left(s_{g i t}\right)$} & -0.004 & -0.034 & -0.003 & -0.002 & -0.007 \\
\hline & $(-0.89)$ & $(-1.13)$ & $(-0.68)$ & $(-0.56)$ & $(-1.75)$ \\
\hline$\left(\log \left(s_{g i t}\right)\right)^{2}$ & & $\begin{array}{c}-0.003 \\
(-1.01)\end{array}$ & & & \\
\hline \multirow{2}{*}{$\log \left(s_{s i t}\right)$} & 0.002 & 0.002 & -0.113 & & \\
\hline & $(0.59)$ & $(0.61)$ & $(-1.94)$ & & \\
\hline \multirow{2}{*}{$\left(\log \left(s_{s i t}\right)\right)^{2}$} & & & -0.010 & & \\
\hline & & & $(-2.00)$ & & \\
\hline \multirow{2}{*}{$\log \left(s_{e i t}\right)$} & & & & -0.091 & \\
\hline & & & & $(-2.42)$ & \\
\hline \multirow{2}{*}{$\left(\log \left(s_{e i t}\right)\right)^{2}$} & & & & -0.007 & \\
\hline & & & & $(-2.34)$ & \\
\hline \multirow{2}{*}{$\log \left(s_{d i t}\right)$} & & & & & -0.073 \\
\hline & & & & & $(-2.03)$ \\
\hline \multirow{2}{*}{$\left(\log \left(s_{d i t}\right)\right)^{2}$} & & & & & -0.006 \\
\hline & & & & & $(-2.35)$ \\
\hline \multirow{2}{*}{$\log \left(n_{i t}+x+\delta\right)$} & -0.022 & -0.021 & -0.021 & -0.021 & -0.018 \\
\hline & $(-2.17)$ & $(-2.08)$ & $(-2.13)$ & $(-2.14)$ & $(-1.73)$ \\
\hline \multirow{2}{*}{$\log \left(u_{i t}\right)$} & -0.00 & -0.007 & -0.007 & -0.008 & -0.006 \\
\hline & $(-2.93)$ & $(-3.01)$ & $(-3.02)$ & $(-3.26)$ & $(-2.55)$ \\
\hline \multirow{2}{*}{$\log \left(1-\tau_{i t}\right)$} & -0.322 & -0.336 & -0.312 & -0.309 & -0.344 \\
\hline & $(-6.77)$ & $(-6.69)$ & $(-6.51)$ & $(-6.48)$ & $(-7.49)$ \\
\hline RSS & 0.099 & 0.098 & 0.097 & 0.097 & 0.093 \\
\hline Durbin-Watson & 1.63 & 1.63 & 1.63 & 1.65 & 1.63 \\
\hline
\end{tabular}

At this point, we have established that the evidence in favor of a positive, significant effect of productive public spending on regional growth is fragile in the case of the Spanish regions over the 1965-1997 period. Our results are not completely surprising. ${ }^{10}$ Mas et al. (1994) recognise that regions with high initial endowment of public capital obtain high growth rates but find that for the period 1967-1979, a negative (but not significant) effect of public capital stock on growth rate of regional value added; for the period 1979-1991, the effect is positive but not statistically significant. De la Fuente and Vives (1995) also find a small impact of public investment on the reduction of territorial imbalances during the 1980s. Finally, Gorostiaga (1999) does not find

\footnotetext{
${ }^{10} \mathrm{We}$ are aware that some aspects of remarkable transcendence in the regional convergence literature are omitted in our paper. See Dolado, Gonzalez-Paramo, and Roldan (1994) and Raymond and Garcia (1995) for the effects of the migratory flows on growth rate; Serrano-Martinez (1999) and De la Fuente (2002) for the technological diffusion and the importance of the regional sectoral structure in a growth theoretical framework; Gorostiaga (1999) for links between human capital and technological progress.
} 
significant coefficients for public investment in a convergence equation for the Spanish regions over a period very similar to ours.

\section{IS IT POSSIBLE THAT PUBLIC INVESTMENT HAS NOT AFFECTED REGIONAL GROWTH?}

The previous results show how public investment has not positively influenced Spanish regional growth between 1965 and 1997. This result is very surprising, of course, as the bulk of regional policies stress the endowment of infrastructure as the most effective instrument for reducing the interregional differences.

However, the existence of a negative effect of (productive) public expenditure on the per capita income growth rate is not a circumstance unknown to development theory. One line of research is based on Uzawa's (1965) and Lucas's (1988) papers. Both papers link the dynamics of growth to the ratio defined by human capital and private capital. With extensions like Mulligan and Sala-i-Martin (1993) and Bosch and Espasa (1999), an inverse relationship can be obtained between public capital/private capital ratio and growth rate in transitional dynamics.

Using a two-sector model of endogenous growth, we consider a representative household that maximizes this standard utility function over time:

$$
\int_{0}^{\infty} \frac{C^{1-\theta}-1}{1-\theta} e^{-\rho t} d t
$$

where $C$ is consumption, $\theta$ is the inverse of the elasticity of intertemporal substitution $(\theta>0)$, and $\rho$ is the rate of time preference $(\rho>0)$. For the sake of simplicity, there is no population growth.

On the production side, we have a broad concept of private capital $(K)$, which includes physical capital $(k)$ and human capital $(h)$. Both of them are combined by a Cobb-Douglas aggregation function: $K=k^{\beta} h^{1-\beta}$. Public capital is accumulated according to the following movement equation:

$$
\dot{G}=Y-C-\delta G=A G^{\alpha}(u K)^{1-\alpha}-C-\delta G,
$$

where $Y$ is the output of goods, $\delta$ is the rate of depreciation, $A$ is a technological parameter, and $u$ is the fraction of private capital used in final goods production. The dynamics of private capital are given by

$$
\dot{K}=B(1-u) K-\delta K
$$

$B$ is also a technological parameter. The rate of depreciation is identical for two kinds of capital, and $(1-u)$ is the fraction of private capital used in intermediate goods production. ${ }^{11}$

\footnotetext{
${ }^{11}$ Notice that public capital has played no role in the accumulation of $K$, which is a restrictive assumption. If we incorporate $G$ into equation (10), we will face very complicated transitional dynamics. However, numerical
} 
Also, we can demonstrate that, under several assumptions, a nonnegative of gross investment constraint is not required (Barro and Sala-i-Martin 1999).

Households maximize (8) subject to (9) and (10). It yields the steady-state values of the variables and their transitional dynamics. Similar to the Uzawa-Lucas model for $K$ and $H$, we can study now which effects the $G / K$ ratio has on growth rate of broad output. Since $Y$ is the output of final goods, we define a broad concept of output as follows:

$$
Q=Y+p B(1-u) K
$$

where $p$ is shadow price of capital in units of $Y{ }^{12}$ While the long-term growth rate of $Q$ is not affected by $G / K$, some results can be drawn for the transitional dynamics. Since the growth rate of broad output $Q$ can be computed as $\gamma_{Q}=\gamma_{Y}-\gamma_{u} \frac{1-\alpha}{1-\alpha-\alpha u}$, where $\gamma_{x}$ is growth rate of $x$, it is possible to demonstrate that $\frac{\partial \gamma_{Q}}{\partial(G / K)}<0$. In other words, the growth rate of the economy towards steady state is inversely related to the $G / K$ ratio. When an economy has a high endowment of infrastructure relative to private capital (high $G / K$ ), its growth rate is below its long-term growth rate and vice versa.

The underlying explanation of this fact comes from the effects of imbalances between $G$ and $K$. If an economy has a $G / K$ ratio above its steady-state value, the marginal product of private capital is high because this is a relatively scarce production factor (compared to infrastructures). This high return means a high cost for the sector that produces private capital, since this is intensive in private capital (a relatively expensive production factor). Then we find that the imbalance between both types of capital is reduced slowly, so the economy growth rate is slow.

Conversely, when the $G / K$ ratio is low, the dynamics of the system provide an incentive to allocate resources to production of the relatively scarce factor. Households realize that their $C / G$ ratio is larger than they desire (its steady-state value), and they reduce their present consumption in favor of production of public capital. (In a more general framework, it would mean paying taxes to finance productive public spending.) This circumstance yields higher growth rates of $Q$ than when a high $G / K$ ratio exists.

Bosch and Espasa (1999) demonstrate what we have just said using Spanish regional data for several periods. It seems that the public investment policy implemented in Spain has given special emphasis to those regions where the social return of infrastructure was smaller. In this sense, we are going to undertake an exercise to test whether our data support this hypothesis. Table 5 shows, in the first column, a classification of the Spanish regions from larger to smaller ratio $\frac{G_{i t}}{K_{i t}}$ over the period 1965 to 1997; the second column places the regions according to values

exercises based on reasonable values for the underlying parameters show how the main results of our restricted framework hold when public capital enters into the equation (10). (See Barro and Sala-i-Martin 1999.)

${ }^{12}$ Formally, $p$ is the ratio between Lagrange multipliers implied in household's optimization problem. 
reached by $\frac{I_{\text {git }}}{I_{\text {pit }}}$, where $I_{g i t}$ is productive public investment in region $i$ in year $t$ and $I_{p i t}$ is the equivalent concept referred in private investment; this last ratio may be interpreted as the share that public investment represents over private investment. Table 6 replicates this structure but uses social public investment and stock instead of $I_{g i t}$ and $G_{i t}$.

The evidence presented in Tables 5 and 6 is suggestive. In the case of productive public capital, regions with high public capital endowments in relation to their private capital (Extremadura, Castilla-La Mancha, Aragon, Castilla-Leon) are those that have received the greatest resources, measured in terms of public investment relative to private investment. Conversely, rich regions as Baleares, Madrid, Cataluña, and Valencia - with small productive public capital-to-private capital ratios - have the lowest relative public investment rates. In the case of social public investment, we find the same pattern (Table 6): regions with high relative endowments in education and health infrastructure are the main beneficiaries of public investment in human capital.

This fact could be partially responsible for the nonsignificance or even the negative effects of public investment on regional growth in Spain from 1965 to 1997. The government has invested in regions where, because of their relatively high endowment of infrastructure, the social return on marginal public capital was the lowest. Public investment policy has not been aimed at maximizing national output; rather, it has apparently pursued redistributive objectives.

\section{TABLE 5}

Productive Public Capital Endowments and Private Investment in the Spanish Regions 1965-1997 (Average Values for Entire Period)

\begin{tabular}{cc|cc}
\hline \multicolumn{1}{c|}{$\frac{G}{K}$} & & \multicolumn{2}{c}{$\frac{I_{G}}{I_{K}}$} \\
\\
Extremadura & 0.1436 & Extremadura & 0.1848 \\
Castilla-La Mancha & 0.1393 & Castilla-La Mancha & 0.1699 \\
Aragon & 0.1366 & Aragon & 0.1536 \\
Castilla-Leon & 0.1161 & Castilla-Leon & 0.1472 \\
La Rioja & 0.0997 & Andalucia & 0.1352 \\
Navarra & 0.0986 & Asturias & 0.1299 \\
Canarias & 0.0926 & Canarias & 0.1180 \\
Andalucia & 0.0916 & Cantabria & 0.1126 \\
Asturias & 0.0748 & La Rioja & 0.1116 \\
Galicia & 0.0725 & Navarra & 0.1053 \\
Murcia & 0.0701 & Murcia & 0.1041 \\
Cantabria & 0.0651 & Pais Vasco & 0.1009 \\
Pais Vasco & 0.0617 & Valencia & 0.0856 \\
Valencia & 0.0581 & Madrid & 0.0855 \\
Cataluña & 0.0481 & Cataluña & 0.0755 \\
Madrid & 0.0472 & Baleares & 0.0731 \\
Baleares & 0.0422 & Galicia & 0.0692 \\
\hline Source: IVIE and Foundation BBVA & & \\
\hline
\end{tabular}




\section{TABLE 6}

Social Public Capital Endowments and Private Investment in the Spanish Regions 1965-1997

(Average Values for Entire Period)

\begin{tabular}{cc|cc}
\hline \multicolumn{2}{c|}{$\frac{G S}{K}$} & & \multicolumn{2}{|c}{$\frac{I_{G S}}{I_{K}}$} \\
\hline Aragón & 0.011814 & Extremadura & 0.014972 \\
La Rioja & 0.011533 & Aragón & 0.014905 \\
Navarra & 0.010720 & Cantabria & 0.014200 \\
Extremadura & 0.010531 & Navarra & 0.013726 \\
Cantabria & 0.009785 & La Rioja & 0.013281 \\
Castilla y León & 0.009263 & Asturias & 0.012507 \\
Andalucía & 0.008916 & Galicia & 0.012390 \\
Castilla-La Mancha & 0.008771 & Castilla y León & 0.012336 \\
Asturias & 0.008426 & Andalucía & 0.011382 \\
Galicia & 0.008337 & Castilla-La Mancha & 0.011266 \\
País Vasco & 0.007471 & País Vasco & 0.010427 \\
Valencia & 0.007025 & Murcia & 0.009683 \\
Canarias & 0.007015 & Canarias & 0.009519 \\
Murcia & 0.006261 & Valencia & 0.009509 \\
Baleares & 0.006110 & Madrid & 0.008423 \\
Madrid & 0.005934 & Baleares & 0.007476 \\
Cataluña & 0.004018 & Cataluña & 0.005510 \\
\hline Source: IVIE and Foundation BBVA & &
\end{tabular}

Conclusions in the same vein can be found in other empirical papers that have studied the effects of infrastructure on economic performance in Spain from a regional perspective. Thus, Bajo, Diaz, and Montavez (1999) claim that public investment did not influence regional growth rates for the richest regions in 1967 (Madrid, Pais Vasco, Cataluña, and Baleares). Moreno et al. (1997) prove that an appropriate endowment of public capital is a necessary but not sufficient condition for economic growth. They show how that the poorest Spanish regions have not taken advantage of public investment to the same extent as others, in spite of being the main recipients.

From a dual approach, Bosca, Escriba, and Daban (1999) find that in the regions where public capital/industrial private capital ratio is higher over the period 1980-1993, infrastructure has a negative shadow price; that is, public capital has not reduced the costs for manufacturing firms. Although the robustness of this result could suffer from specification problems, the association found suggests that an inadequate amount of private capital could prevent any positive effects of public capital from manifesting themselves in larger growth rates. The largest shadow prices for infrastructure were found in the most industrialized regions, a result that reaffirms the former intuition.

\section{CONCLUSIONS}

Proponents of regional policies argue that the stocks of public and human capital are important determinants of regional growth. While the empirical support of the relationship between public capital and regional output is not unanimous, there have been few studies that develop linkages with the broader literature on economic convergence. The purpose of this 
paper has been to examine whether the economic performance of Spanish regions has been converging or diverging since 1965 and whether public investment policies have affected regional economic growth.

The results from the analysis support the conditional convergence hypothesis among the Spanish regions. However, it is also found that the contribution of variables that can be influenced by policy is not always as expected: while investment in human capital is positively associated with regional growth in most cases, public productive investment apparently retards performance. These findings remained unaltered after a set of robustness checks. A tentative explanation for this unconventional effect is that public investment has been directed to those regions with higher public-to-private capital ratios.

The implications of these results for regional policies are not very clear. While investment in human capital is important, the specific nature of public physical investments and the specifics of the target regions may render investment inefficient. It appears that the impact of public investment on regional performance depends on region-specific characteristics such as technical efficiency, organizational capacity, productive specialization, and the like. This last circumstance will become a very important issue in the future enlargement of European Union, with very heterogeneous countries as targets of regional funds. The effectiveness of public investment will depend on different factors beyond the resources devoted to infrastructures. It may be concluded that there are no simple recipes for effective regional investment policies.

\section{DATA APPENDIX}

The aim of this appendix is to offer information about the variables employed as well as the data sources we used. The variable $y_{i t}$ corresponds to per active worker regional GDP, with biannual observations. The choice of active population for measuring per capita regional output is intentional. After using figures corresponding to employed population and working-age population, we checked that the best behavior of the estimations happens for active population. This circumstance is especially clear if our purpose is to control for the regional business cycle through the unemployment rate $\left(u_{i t}\right)$, since some papers point out that the regional differentials in unemployment rates have transcendence on the process of regional convergence in Spain (Bentolila and Jimeno 1995; Raymond and Garcia 1995).

The variable $s_{p i t}$ is defined as the ratio of private investment in physical capital over regional GDP, and $s_{g i t}$ is the share of productive public investment (roads, hydraulic infrastructures, urban structures, ports) over the regional GDP. The variable $s_{h i t}$ is proxied by three series: $s_{e i t}$ is public investment devoted to education as a percentage of the regional GDP; $s_{d i t}$ is an equivalent concept but corresponding to investment in health; $s_{s i t}$ is the share of public investment in both education and health in the regional GDP. For these categories, we considered productive or social capital spending by central, regional, and local governments as well as by the Social Security.

In the group of demographic variables, $n_{i t}$ is the average growth rate of active population in each time span (two years). $x$ is technical progress rate; its value has been fixed at 0.02 . The symbol $\delta$ is the rate of capital goods depreciation that we assume is constant and common for all 
three types of assets considered in this paper, with its value fixed at 0.05 . The estimates presented here are robust to changes in these parameters.

All the previous variables have been obtained from the Foundation BBVA (Banco Bilbao Vizcaya Argentaria) and the IVIE (Instituto Valenciano de Investigaciones Economicas). Many of them are available at http://w3.grupobbva.com/TLFB/TLFBindex.htm and http://www.ivie.es/. Additional information on these data can be found at these Internet sites and in Mas et al. (1996).

The variable $\tau_{i t}$ is the share of tax resources collected by the government over the regional GDP. The series has been extracted from the Foundation BBVA (over various years). This concept consists of social security contributions and direct and indirect taxes. All the previous monetary variables are measured at 1986 prices. Human capital stock, $h_{i t}$, is the share of working-age population with secondary and university studies. The data have been taken from IVIE (http://www.ivie.es/). The number of observations has oscillated between 269 and 255 . It corresponds to data for 17 regions over 16 years. For the unemployment rate, three observations with values very near zero have been removed to avoid the distortion of the logarithmic transformation of data.

\section{APPENDIX TABLE}

Summary of Variables, Abbreviations, and Definitions

\begin{tabular}{|c|c|c|c|}
\hline$y_{i t}$ & per active worker regional GDP (biannual) & $\tau_{i t}$ & $\begin{array}{l}\text { ratio of tax resources collected by government over } \\
\text { the regional GDP }\end{array}$ \\
\hline$S_{\text {pit }}$ & $\begin{array}{l}\text { ratio of private investment in physical capital over } \\
\text { regional GDP }\end{array}$ & $n_{i t}$ & $\begin{array}{l}\text { average growth rate of active population in each } \\
\text { time span (two years) }\end{array}$ \\
\hline$s_{\text {git }}$ & $\begin{array}{l}\text { ratio of productive public investment (roads, } \\
\text { hydraulic infrastructures, urban structures, ports) } \\
\text { over the regional GDP }\end{array}$ & $x$ & $\begin{array}{l}\text { exogenous technical progress rate whose value has } \\
\text { been fixed at } 0.02\end{array}$ \\
\hline$S_{\text {eit }}$ & $\begin{array}{l}\text { ratio of public investment devoted to education as } \\
\text { percentage of the regional GDP }\end{array}$ & $\delta$ & $\begin{array}{l}\text { rate of capital goods depreciation that we suppose } \\
\text { constant and common to all the three types of assets } \\
\text { considered in this paper; its value is fixed at } 0.05\end{array}$ \\
\hline$s_{\text {dit }}$ & $\begin{array}{l}\text { ratio of public investment in health as percentage of } \\
\text { the regional GDP. }\end{array}$ & $h_{i t}$ & $\begin{array}{l}\text { share of working-age population with secondary and } \\
\text { university studies }\end{array}$ \\
\hline$S_{\text {sit }}$ & $\begin{array}{l}\text { ratio of public investment in both education and } \\
\text { health as percentage of the regional GDP }\end{array}$ & $u_{i t}$ & unemployment rate \\
\hline
\end{tabular}

\section{REFERENCES}

Arellano, M., 1988. “An Alternative Transformation for Fixed Effects Model with Predetermined Variables," Applied Economics Discussion Paper No. 57. Institute of Economics and Statistics: Oxford.

Arellano, M. and S.R. Bond, 1991. "Some Tests of Specification for Panel Data: Monte Carlo Evidence and an Application to Employment Equations," Review of Economic Studies 58, 277-297. 
Arrow, K.J. and M. Kurz, 1970. Public Investment, the Rate of Return and Optimal Fiscal Policy. Johns Hopkins Press: Baltimore.

Aschauer, D.A., 1989. “Is Public Expenditure Productive," Journal of Monetary Economics 23, 177-200.

Aschauer, D.A., 2000. "Do States Optimize? Public Capital and Economic Growth,” The Annals of Regional Science 34, 343-363.

Bajo-Rubio, O., 2000. "A Further Generalization of the Solow Model: The Role of the Public Sector," Economics Letters 68, 79-84.

Bajo-Rubio, O., C. Diaz, and D. Montavez, 1999. "Politica Fiscal y Crecimiento en las Comunidades Autonomas Españolas," Papeles de Economia Española 80, 203-218.

Barro, R.J., 1990. “Government Spending in a Simple Model of Endogenous Growth,” Journal of Political Economy 98(5), 103-125.

Barro, R., 1991. "Economic Growth in a Cross-Section of Countries," Quarterly Journal of Economics 106(2), 407-443.

Barro, R.J. and X. Sala-i-Martin, 1999. Economic Growth. The MIT Press: Cambridge, MA.

Bentolila, S. and J.F. Jimeno, 1995. "Regional Unemployment Persistence Spain, 1976-1994," Centre for Economic Policy Research Discussion Paper No. 1259: London.

Biehl, D. (ed.), 1986. “The Contribution of Infrastructure to Regional Development,” Final Report of the Infrastructure Study Group, Commission of the European Communities: Luxemburg.

Bosca, J.E., J. Escriba, and T. Daban, 1999. "Capital Privado e Infraestructuras en la Produccion Industrial Regional," Revista de Economia Aplicada 21, 61-94.

Bosch, N. and M. Espasa, 1999. “¿Con Que Criterios Invierte el Sector Publico Central?” in A. Castells and N. Bosch (eds.), Desequilibrios Territoriales en España y Europa. Ariel Economia: Barcelona.

Clarida, R.H., 1993. "International Capital Mobility, Public Investment and Economic Growth," National Bureau of Economic Research Working Paper, No. 4506: Cambridge, MA.

Currais, L. and B. Rivera, 1999a. "Income Variation and Health Expenditures: Evidence for OECD Countries," Review of Development Economics 3(3), 258-267.

Currais, L. and B. Rivera, 1999b. "Economic Growth and Health: Direct Impact or Reverse Causation," Applied Economics Letters 6(11), 761-764. 
Dalenberg, D.R. and M.D. Partridge, 1995. "The Effects of Taxes, Expenditures and Public Infrastructure on Metropolitan Area Employment," Journal of Regional Science 35(4), $617-$ 640.

Dalenberg, D.R. and M.D. Partridge, 1997. "Public Infrastructure and Wages: Public Capital's Role as a Productive Input and Household Amenity," Land Economics 73, 268-284.

Dasgupta, D., 1999. “Growth Versus Welfare in a Model of Nonrival Infrastructure,” Journal of Development Economics 58, 359-389.

De la Fuente, A., 1997. "Fiscal Policy and Growth in the OECD," D.T. 97007, Direccion General de Analisis y Programacion Presupuestaria, Ministerio de Economia y Hacienda: Madrid. Available at: http://www.igae.minhac.es/documentos/Documentos.htm

De la Fuente, A., 2000. "Convergence Across Countries and Regions: Theory and Empirics," EIB Papers/BEI Cahiers 5(2), 25-46.

De la Fuente, A, 2002. "On the Sources of Convergence: A Close Look at the Spanish Regions," European Economic Review 46(3), 569-599.

De la Fuente, A. and X. Vives, 1995. "Regional Policy and Spain: Infrastructure and Education as Instruments of Regional Policy: Evidence from Spain," Economic Policy 20, 11-54.

De Long, J.B. and L. Summers, 1991. "Equipment Investment and Economic Growth," Quarterly Journal of Economics 106(2), 445-502.

Dolado, J.J., J.M. Gonzalez-Paramo, and J.M. Roldan, 1994. “Convergencia Economica Entre las Provincias Españolas," Moneda y Credito 198, 81-131.

Easterly, W. and S. Rebelo, 1993. "Fiscal Policy and Economic Growth: An Empirical Investigation," Journal of Monetary Economics 32, 417-458.

Evans, P. and G. Karras, 1994. "Is Government Capital Productive? Evidence From a Panel of Seven Countries," Journal of Macroeconomics 16(2), 271-279.

Fisher, W.H. and S.J. Turnovsky, 1998. "Public Investment, Congestion and Private Capital Accumulation," The Economic Journal 108, 399-413.

Foundation BBVA, 1999. Renta Nacional de España y su Distribucion Provincial. Serie Homogenea. Años 1955 a 1993 y avances 1994 a 1997. Foundation BBVA: Bilbao.

Foundation BBVA, 2000. Renta Nacional de España y su Distribucion Provincial. Año 1995 y avances 1996 a 1999. Foundation BBVA: Bilbao. 
Futagami, K., Y. Morita, and A. Shibata, 1993. "Dynamic Analysis of an Endogenous Growth Model with Public Capital,” Scandinavian Journal of Economics 95(4), 607-625.

Glomm, G. and B. Ravikumar, 1994. "Public Investment in Infrastructure in a Simple Growth Model," Journal of Economic Dynamics and Control 18, 1173-1187.

Gonzalez-Paramo, J.M., 1995. "Infraestructuras, Productividad y Bienestar," Investigaciones Economicas 19, 155-168.

Gorostiaga, A., 1999. "¿Como Afectan el Capital Publico y el Capital Humano al Crecimiento?: Un Analisis para las Regiones Españolas en el Marco Neoclásico," Investigaciones Economicas 23(1), 95-114.

Hausman, J.A., 1978. "Specification Tests in Econometrics,” Econometrica 46, 1251-1271.

Holtz-Eakin, D., 1994. "Public-Sector Capital and the Productivity Puzzle," Review of Economics and Statistics 76(1), 12-21.

Hulten, C.R. and R.M. Schwab, 1993. "Endogenous Growth, Public Capital and the Convergence of Regional Manufacturing Industries," National Bureau of Economic Research Working Paper No. 4538: Cambridge, MA.

Islam, N., 1995. “Growth Empirics: A Panel Data Approach,” Quarterly Journal of Economics 95, 1127-1170.

Jones, L.E., R.E. Manuelli, and P.E. Rossi, 1993. "Optimal Taxation in Models of Endogenous Growth," Journal of Political Economy 101(3), 485-517.

King, R.G. and R. Levine, 1994. "Capital Fundamentalism, Economic Development and Economic Growth,” Carnegie-Rochester Conference Series on Public Policy 40, 259-292.

Kneller, R., M.F. Bleaney, and N. Gemmell, 1999. "Fiscal Policy and Growth: Evidence from OECD Countries," Journal of Public Economics 74, 171-190.

Knight, M., N. Loayza, and D. Villanueva, 1993. "Testing the Neoclassical Theory of Economic Growth: A Panel Data Approach," IMF Staff Papers 40, 512-541.

Lucas, R.E., 1988. "On the Mechanics of Development Planning," Journal of Monetary Economics 22(1), 3-42.

Mankiw, N.G., D. Romer, and D. Weil, 1992. "A Contribution to the Empirics of Economic Growth," Quarterly Journal of Economics 107, 407-437.

Mas, M., J. Maudos, F. Perez, and E. Uriel, 1994. "Disparidades Regionales y Convergencia en las Comunidades Autonomas," Revista de Economia Aplicada 4(2), 129-148. 
Mas, M., J. Maudos, F. Perez, and E. Uriel, 1996. El Stock de Capital en España y sus Comunidades Autonomas. Foundation BBV: Bilbao.

Mendoza, E., G. Milesi-Ferreti, and P. Asea, 1997. “On the Ineffectiveness of Tax Policy in Altering Long-Run Growth: Harberger's Superneutrality Conjecture,” Journal of Public Economics 66, 99-126.

Moreno, R., M. Artis, E. Lopez-Bazo, and J. Suriñach, 1997. "Evidence on the Complex Link Between Infrastructure and Regional Growth," International Journal of Development Planning Literature 12(1-2), 81-108.

Mulligan, C.B. and X. Sala-i-Martin, 1993. "Transitional Dynamics in Two-Sector Models of Endogenous Growth," Quarterly Journal of Economics 108(3), 737-773.

Munnell, A.H., 1990. Is There a Shortfall in Public Investment?" Conference Series No. 34. Federal Reserve Bank of Boston: Boston.

Raymond, J.L. and B. Garcia, 1995. "Distribucion Regional de la Renta y Movimientos Migratorios," Papeles de Economia Española 67, 185-201.

Rivera, B. and L. Currais, 2000. "The Contribution of Publicly Provided Health to Growth and to Productivity," Estudos Economicos 30(2), 191-206.

Serrano-Martinez, L., 1999. “Capital Humano, Estructura Sectorial y Crecimiento en las Regiones Españolas,” Investigaciones Economicas 23(2), 225-249.

Solow, R., 1956. "A Contribution to the Theory of Economic Growth," Quarterly Journal of Economics 70, 65-94.

Sturm, J.B., 1998. Public Capital Expenditure in OECD Countries. Edward Elgar: Cheltenham.

Thomas, B., 1996. "Infrastructure and Regional Growth in the European Union," Birmingham Economics Discussion Paper 96-25: Birmingham.

Uzawa, H., 1965. "Optimal Technical Change in Aggregative Model in Economic Growth," International Economic Review 6, 18-31.

Vickerman, R.W., 1991. "Introduction," in R.W. Vickerman (ed.) Infrastructure and Regional Development. Pion: London.

Wolf, E.N., 2000. "Human Capital Investment and Economic Growth: Exploring the CrossCountry Evidence," Structural Change and Economic Dynamics 11, 433-472. 